Al-Manhaj: Jurnal Hukum dan Pranata Sosial Islam

Vol. : : 3 (1), 2021, 89-114

P-ISSN : 2686-1607

E-ISSN : 2686-4819

\title{
PREMARITAL CHECK UP DALAM PERSPEKTIF MAQASHID AL-SYARI'AH
}

\author{
Khusni Tamrin \\ Universitas Islam Negeri Raden Intan Lampung \\ email: khusni.tamrin@gmail.com
}

\begin{abstract}
Premarital health check-up is a preventive measure to avoid unwanted things, in order to form a family and produce perfect offspring. In this paper aims to discuss premarital health tests (premarital check up) perspective maqâshid al-syarî'ah. In this research the method used is a qualitative research method, the type of research research, with a philosophical approach and medical approach, the theory of al-shari'ah maqasid. Based on the results of the study it was found that, conducting pre-marital health tests it can be known earlier various possible illnesses suffered so that action can be taken earlier to prevent various difficulties that will come, this is in accordance with the theory of Saad ad-dzarî'ah or taking steps preventive from anything that can threaten. In the analysis of sharia maqasid, namely guarding religion (hifzh dîn), guarding the soul (hifzh nafs), guarding offspring (hifzh nasl), guarding reason (hizfh 'aql) and protecting wealth (hizfh mâl), premarital health tests in this case are more emphasized by guarding the soul (hifzh nafs) and guarding offspring (hifzh nasl). Pre-marital medical tests in the view of Maqâshid Al-Syarî'ah are recommended because they see the many benefits in the examination.
\end{abstract}

Keywords: health test, premarital, maqasid shari'ah

Abstrak: Pemeriksaan kesehatan sebelum menikah (premarital check up) merupakan suatu tindakan preventif untuk menghindari hal yang tidak di inginkan, dalam rangka untuk membentuk 
keluarga dan menghasilkan keturunan yang sempurna. Dalam tulisan ini bertujuan untuk membahas tes kesehatan pranikah (premarital check up) perspektif maqashid al-syari'ah. Pada penelitan ini metode yang digunakan adalah metode penelitian kualitatif, jenis penelitian library research, dengan pendekatan filosofis dan pendekatan medis, teori maqasid al-syari'ah. Berdasarkan hasil penelitian ditemukan bahwa, Melakukan tes kesehatan pra nikah maka dapat diketahui lebih awal berbagai kemungkinan penyakit yang di derita sehingga dapat diambil tindakan lebih dini untuk mencegah berbagai kesulitan yang akan datang, hal ini sesuai dengan teori saad ad-dzarî'ah atau pengambilan langkah preventif terhadap segala sesuatu yang dapat mengancam. Dalam analisa maqasid syariah yaitu menjaga agama (hifzh dîn), menjaga jiwa (hifzh nafs), menjaga keturunan (hifzh nasl), menjaga akal (hizfh 'aql) dan menjaga harta (hizfh mâl), tes kesehatan pranikah dalam hal ini lebih ditekankan sesuai dengan menjaga jiwa (hifzh nafs) dan menjaga keturunan (hifzh nasl). Tes kesehatan pra nikah dalam pandangan Maqâshid Al-Syarî'ah dianjurkan karena melihat banyaknya manfaat di dalam pemeriksaan tersebut.

Kata Kunci: tes kesehatan, pranikah, maqasid syari'ah.

\section{PENDAHULUAN}

Tujuan utama melakukan pemeriksaan kesehatan pranikah adalah untuk membangun keluarga sehat sejahtera dengan mengetahui kemungkinan kondisi kesehatan anak yang akan dilahirkan (riwayat kesehatan kedua orang tuanya), termasuk soal genetik, penyakit kronis, penyakit infeksi yang dapat mempengaruhi kondisi kesehatan keturunan. Dari tujuan tersebut tampaklah jelas bahwa pemeriksaan ini sangat memperhatikan permasalahan keturunan. Maka dari itu dengan melakukan 
pemeriksaan kesehatan pranikah berarti kita telah melaksanakan pemeliharaan keturunan yang diperintahkan oleh agama.

Selain untuk pertimbangan memperoleh keturunan yang sehat fisik dan akalnya, pemeriksaan kesehatan sebelum menikah juga diharapkan dapat mencegah terjadinya penularan penyakit melalui hubungan suami istri yang terjadi bilamana salah satu pasangan mempunyai riwayat penyakit menular, seperti penyakit HIV dan AIDS, ${ }^{1}$ yang selama ini masih sulit untuk disembuhkan. Penyakit tersebut adalah penyakit yang muncul atau datang bilamana ada seseorang yang berganti-ganti pasangan dalam melakukan hubungan suami istri. Korelasi dengan tes kesehatan pranikah adalah diharapkan calon mempelai baik laki-laki maupun perempuan dapat diketahui apakah memilik penyakit tersebut atau tidak.

Proses tes kesehatan pranikah biasanya di lakukan di rumah sakit atau klinik yang sudah memiliki peralatan yang memadai untuk melakukan tes kesehatan. Pemeriksaan kesehatan sebelum menikah (premarital check up) dianggap salah satu sebagai tindakan preventif untuk suatu pekara yang dianggap akan merugikan dikemudian hari.

Setelah melakukan tes kesehatan pranikah, calon mempelai laki-laki dan calon mempelai perempuan akan melihat hasil yang dikeluarkan oleh pihak klinik terkait kondisinya. Setelah melihat hasil dari tes kesehatan tersebut maka keputusannya

1 HIV (Human Immuno Devesiensi) adalah virus yang hanya hidup dalam tubuh manusia, yang dapat merusak daya kekebalan tubuh manusia. Sedangkan AIDS (Acguired Immuno Deviensi Syndromer) adalah kumpulan gejala menurunnya gejala kekebalan tubuh terhadap serangan penyakit dari luar. 
dikembalikan kepada kedua calon mempelai dan kelurga masingmasing, untuk mengambil keputusan yang terbaik yaitu apakah akan dilanjutkan ke jenjang pernikahan atau tidak melanjutkan ke jenjang pernikahan (mengakhiri hubungan) dikarenakan memiliki penyakit yang tidak diinginkan. Sebagai umat manusia hanya bisa melakukan usaha untuk menghindari penyakit kepada diri sendiri dan keturunan, oleh karena itu keputusan yang diambil harus arif bijaksana dalam sebuah tindakan baik menyangkut terhadap diri sendiri maupun orang lain.

Berdasarkan uraian di atas maka paper ini akan membahas tes kesehatan pranikah (premarital check up) perspektif maqâshid al-syarî'ah. Pada penelitan ini metode yang digunakan adalah metode penelitian kualitatif, jenis penelitian library research, dengan pendekatan filosofis dan pendekatan medis, teori maqasid al-syari'ah.

\section{PENGERTIAN MAQASHID AL-SYARI'AH}

Ditinjau dari bahasa kata maqashid al-syari'ah terdiri dua kata yaitu maqashid dan al-syari'ah. Kata maqashid merupakan bentuk kata jamak (plural) yang berasal dari kata tunggal mashid dan maqshad (keduanya berupa mashdar mimi), ${ }^{2}$ yang berarti kesengajaan atau tujuan. Sedangkan kata al-syari'ah secara bahasa memiliki arti jalan menuju sumber air.

2 Mashdar mimi adalah bentuk mashdar yang mendapat awalan tambahan huruf mim (mim zaidah) 
Menurut Imam Al-Ghazali semua hukum syariah itu bertujuan mendekatkan manusia kepada Allah dan mencapai kebahagiaan abadi. Hal ini hanya bisa dicapai dengan menyadari bahwa Allah adalah Tuhan dan kita hanyalah hamba yang ditugaskan mengabdi kepada-Nya. Tujuan ini hanya bisa sempurna bila kelestarian hidup di dunia juga terjaga, sehingga kelestarian hidup pun menjadi tujuan syariah. Seperti menjaga jiwa, akal, keturunan dan harta. ${ }^{3}$

Dapat disimpulkan bahwa maqashid al-syari'ah adalah tujuan atau maksud diturunkannya syari'at untuk di laksanakan oleh manusia yang berguna untuk kemaslahatan baik secara personal maupun masyarakat, karena menjamin kebutuhan pokok manusia seperti agama, jiwa, keturunan, akal dan harta. Dengan adanya maqashid al-syari'ah maka manusia akan merasa tenteram dan aman dalam menjalani kehidupan.

\section{LANDASAN HUKUM MAQASHID AL-SYARI'AH}

Maqashid al-syari'ah terkadung dalam al-Qur'an, dalam surat al-An'am (6): 151-152 yang artinya "Katakanlah (Muhammad), marilah aku bacakan apa yang diharamkan Tuhan kepadamu. Jangan mempersekutukan-Nya dengan apapun, berbuat baik kepada ibu bapak, janganlah membunuh anak-anakmu karena miskin. Kami-lah yang Memberi rezeki kepadamu dan kepada mereka; janganlah kamu mendekati perbuatan yang keji, baik yang terlihat ataupun yang tersembunya, janganlah kamu membunuh 
orang yang Diharamkan Allah kecuali dengan alasan yang benar, demikian Dia Memerintahkan kepadamu agar kamu mengerti" (151) "Dan janganlah kamu mendekati harta anak yatim, kecuali dengan cara yang lebih manfaat, sampai dia mencapai (usia) dewasa. Dan sempurnakanlah takaran dan timbangan dengan adil. Kami tidak membebeani seseorang melainkan dengan kesanggupannya. Apabila kamu berbicara, bicaralah sejujurnya, sekalipun dia kerebat(mu) dan penuhilan janji Allah. Demikian Dia Memerintahkan kepadamu agar kamu ingat." (152). Dari ayat tersebut sudah terkandung dharuriyat yang lima yang merupakan kebutuhan pokok manusia, yaitu memelihara agama, memelihara jiwa, memlihara keturunan, memlihara harta, memelihara akal.

\section{TINGKATAN-TINGKATAN MAQASHID AL-SYARI'AH}

Ada beberapa tingkatan maqashid al-syari'ah berdasarkan pembagian kebutuhannya, yaitu dibagi menjadi tiga bagian maqashid ad-daruriyat, maqashid hajiyyat dan maqashid tahsiniyyat. Berikut penjelasan tentang ketiga tingkatan maqashid al-syari'ah :

\section{Maqashid Ad-Daruriyat (Kebutuhan Primer)}

Dari segi bahasa ad-dharuriyyat dapat diartikan maknanya sebagai kebutuhan mendesak atau kebutuhan darurat. Sehingga dalam kebutuhan dharuriyyat atau kebutuhan primer ini tidak terpenuhi, maka akan mengancam keselamatan umat manusia di dunia maupun di akhirat. ${ }^{4}$ Berikut ini tingkatan ad-dharuriyyat :

\footnotetext{
${ }^{4}$ A. Djazuli, Fiqh Siyasah (Bandung : Prenada Media, 2003), 397.
} 
1. Memelihara Agama

Dalam tingkat ad-dharûriyyât yaitu memelihara agama dalam tingkatan pokok atau primer dengan cara menjalankan sholat lima waktu. Apabila sholat wajib yang lima waktu tidak dilaksanakan maka akan mengancam keutuhan dalam beragama.

2. Memelihara Jiwa

Memelihara jiwa dalam tingkat ad-dharûriyyât yaitu dengan cara memenuhi kebutuhan pokok bagi jiwa, yaitu dengan makan dan minum. Apabila kebutuhan ini tidak terpenuhi yaitu makan dan minum, makan akan mengancam keutuhan jiwa tersebut.

3. Memelihara Akal

Memelihara akal dalam tingkatan ad-dharûriyyât yaitu dengan cara menjauhi mengkonsumsi minuman yang memaabukkan (khmr), sabu-sabu dan obat-obatan terlarang lainnya. oleh sebab itu dalam agama dilarang untuk mengkonsumsinya, jika peringatan itu tidak ditaati maka akan mengancam fungsi dari akal itu sendiri.

4. Memelihara Keturunan

Memelihara keturunan dalam tingkatan ad-dharûriyyât yaitu dengan cara diperintahkannya melakukan pernikahan dan dilarang untuk melakukan perzinahan, apabila syariat tersebut tidak ditaati maka akan mengancam keutuhan keturunan yaitu akan terhapusnya nasab antara ayah dengan anak. 
5. Memelihara Harta

Memelihara harta dalam tingkatan ad-dharûriyyât yaitu dengan cara diperintahkan memiliki harta dengan cara yang benar dan dilarang untuk mengambil harta milik orang lain dengan cara mencuri, merampas serta merampok. Apabila perintah dan larangan tersebut tidak di laksanakan maka akan mengancam keutuhan harta.

\section{Maqashid Hajiyyat (Kebutuhan Sekunder)}

Maqâshid Hajiyyat secara bahasa merupakan kebutuhankebutuhan sekunder bagi manusia. Apabila kebutuhan ini tidak terwujud, maka tidak akan mengancam keselamatan, namun akan menyulitkan. Untuk menghilangkan kesulitan tersebut, dalam Islam terdapat hukum rukhshah (keringanan), yaitu hukum yang dibutuhkan untuk meringankan beban, sehinggah hukum dapat dilaksanakan tanpa rasa tertekan dan terkekang.5 Berikut ini tingkatan Hajiyyat, sebagai berikut :

1. Memelihara Agama

Memelihara agama dalam tingkatan hâjiyyât adalah dengan cara melaksanakan perintah dalam beragama dan menghindari adanya kesulitan. Seperti mengerjakan jama' dan qasar sholat ketika perjalanan jauh.

2. Memelihara Jiwa

Memelihara jiwa dalam tingkatan hâjiyyât yaitu dengan cara mencari makanan yang lezat ataupun bepergian

5 Yusuf Al-Qardhawi, Fiqih Praktis Bagi Kehidupan Modern, (Kairo : Maktabah Wabah, 1999), h. 79. 
menggunakan kendaraan. Apabila dalam tingkatan ini tidak terpenuhi maka tidak akan mengancam keutuhan jiwa, akan tetapi dapat mempersulitnya.

3. Memelihara Akal

Memelihara akal dalam tingkatan hâjiyyât adalah dengan cara menuntut ilmu atau belajar, jika tidak belajar maka tidak akan mengancam akal. Namun dapat menyulitkan diri sendiri akibat kebodahan pada dirinya.

4. Memelihara Keturunan

Memelihara keturunan dalam tingkatan hâjiyyât adalah dengan cara diberikannya hak talak kepada seorang suami, jika dalam keadaan rumah tangga yang tidak harmonis maka suami boleh menggunakannya. Jika hak tersebut bukan terletak pada suami maka suami akan kesulitan jika rumah tangganya sudah tidak harmonis.

5. Memelihara Harta

Memelihara harta dalam tingkatan hâjiyyât adalah dengan cara disyariatkannya jual-beli, jika syariat ini tidak dilakukan maka tidak akan mengancam keutuhan harta. Akan tetapi menyulitkan bagi pemilik benda dan orang yang mempunyai modal.

\section{Maqashid Tahsiniyyat (Kebutuhan Tersier)}

Secara bahasa tahsiniyyat berarti suatu hal penyempurna. Pada tingkat kebutuhan tahsiniyyat yaitu merupakan tingkat kebutuhan pelengkap. Oleh sebab itu jika kebutuhan ini tidak terpenuhi, maka tidak akan mengancam dan tidak akan 
menyembabkan kesulitan. ${ }^{6}$ Berikut adalah uraian dari Maqashid tingkat tahsiniyyat:

1. Memelihara Agama

Memelihara agama dalam tingkat tahsiniyyât adalah dengan cara mengiti petunjuk yang ada dalam agama dan menjunjung tinggi norma-norma yang ada dalam masyarakat serta melengkapi segala kebutuhan dalam menjalankan agama. Memelihara dalam tingkat ini yaitu dengan menutup aurat, membersihkan pakaian, badan dan tempat tinggal. Artinya jika seseorang tidak melakukan dalam tingkat ini maka tidak akan mengancam keutuhan agama, hanya saja akan menyulitkannya.

2. Memelihara Jiwa

Memelihara jiwa dalam tingkatan tahsiniyyât adalah dengan cara ditetapkannya tata cara dalam makan dan minum yaitu dengan cara memakai tangan kanan dan tidak berdiri serta tidak berlebihan. Apabila aturan ini dilanggar maka tidak akan mengancam keberadaan jiwa, hanya saja akan menyulitkannya karena aturan ini adalah erat hubungannya dengan sopan-santun.

3. Memelihara Akal

Memelihara akal dalam tingkatan tahsiniyyât yaitu dengan cara dilarang untuk menghayal ataupun beranganangan dan mendengarkan hal-hal yang kurang bermanfaat. 
Apabila dilanggar maka tidak akan mencam keberadaan akal, namun hal tersebut adalah bentuk menyia-nyiakan akal.

4. Memelihara Keturunan

Memelihara keturunan dalam tingkatan tahsiniyyât adalah disyariatkannya melakukan khitbah atau lamaran dan walimatul 'ursy dalam rangkaian proses pernikahan. Apabila hal tersebut tidak dilakukan maka tidak akan menyebabkan terncamnya keturunan, hanya saja aturan tersebut sudah ditetapkan oleh syariat.

5. Memelihara Harta

Memelihara harta dalam tingkatan tahsiniyyât adalah dengan cara menghindari penipuan dalam proses jual beli atau usaha. Jika aturan ini tidak dilaksanakan maka akan merugikan pihak yang tertipu.

\section{TES KESEHATAN PRANIKAH (PREMARITAL CHECK UP)}

Menurut organisasi dunia di bawah naungan Perserikatan Bangsa-Bangsa (PBB) yang membidangi tentang kesehatan yaitu WHO (World Health Orgaization) menyebutkan bahwa yang dimaksud dengan sehat adalah memperbaiki kondisi manusia, baik jasmani, rohani ataupun akal, sosial dan bukan semata-mata memberantas penyakit. ${ }^{7}$ Dalam pengertian yang dimaksud oleh WHO tersebut adalah bukan memberantas penyakit yang ada namun memperbaiki kondisi manusia dari keterbelangan kondisi kesehatan dengan cara menggerakkan pola hidup sehat,

${ }^{7}$ Ahmad Syauqi Al-Fanjari, Nilai Kesehatan Dalam Syariat Islam (Jakarta : Bumi Aksara, 1993), 4. 
mengurangi kurang gizi dan termasuk juga mengajak masyarakat agar memperhatikan lingkungan.

Majelis Ulama Indonesia (MUI) dalam Musyawarah Nasional (MUNAS) Ulama tahun 1983 merumuskan kesehatan sebagai ketahanan jasmaniah, ruhaniyah dan sosial yang dimiliki manusia sebagai karunia Allah yang wajib di syukuri dengan mengamalkan tuntunan-Nya dan memelihara serta mengembangkannya. ${ }^{8}$ Senanda dengan pengertian yang dikemukakan oleh WHO bahwa jasmani, rohani dan sosial merupakan kesehatan yang harus dijaga dan dipertahankan. Namun MUI juga menekankan bahwa umat harus selalu bersyukur bahwa telah dikaruniai kesehatan oleh Sang Maha Pencipta.

Dari pengertian di atas dapat diambil kesimpulan bahwa tes kesehatan pranikah adalah suatu rangkaian proses yang dilakukan oleh seseorang calon pasangan suami isteri atau individu yang akan menikah untuk mengetahui keadaan kesehatan dirinya dengan cara memeriksakan dirinya ke klinik ataupun rumah sakit.

Dasar hukum yang spesifik memperintahkan untuk melakukan pemeriksaan kesehatan sebelum menikah tidak ditemukan, namun terdapat dalil-dalil yang memerintahkan untuk menjaga kesehatan. Salah satunya dalam surat Al-An'am (6), yang artinya sebagai berikut : "katakanlah, tidak kudapati di dalam apa yang diwahyukan kepadaku, sesuatu yang diharamkan memakannya bagi yang ingin memakannya, kecuali daging hewan

8 M. Quraish Shihab, Wawasan al-Qur'an (Bandung : Mizan, 1998), 182. 
yang mati (bangkai), darang yang mengalir, daging babi-karena semua itu kotor-atau hewan yang disembelih bukan atas (nama) Allah. Tetapi barangsiapa terpaksa bukan karena menginginkan dan tidak melebihi (batas darurat) maka sungguh, Tuhan-mu Maha Pengampun, Maha Penyayang."

Dalam ayat tersebut diperintahkan untuk menjaga kesehatan yang telah diberikan dengan cara menjauhi makananmakanan yang diharamkan seperti bangkai, darah yang mengalir (cair), daging babi dan binatang yang disembelih bukan atas nama Allah. Karena dalam larangan tersebut mengandung suatu kemaslahatan bagi manusia, apabila dalam keadaan terpaksa maka makanan tersebut boleh untuk dimakan hanya sebatas untuk bertahan hidup bukan untuk mengenyangkan diri. Sedangkan dasar hukum dari Hadis tentang kesehatan yang artinya sebagi berikut;"Dari Ibnu 'Abbas R.A berkata : bahwa Nabi Muhammad SAW bersabda : banyak manusia merugi karena dua nikmat kesehatan dan waktu luang" (H.R Bukhari).

\section{PROSES TES KESEHATAN PRANIKAH (PREMARITAL CHECK UP)}

Pada dasarnya pemeriksaan kesehatan sebelum menikah adalah proses tindakan preventif dari berbagai hal yang tidak diinginkan seperti penularan penyakit dan pencegahan dari penyakit yang lebih parah lagi. Pemeriksaan kesehatan sebelum menikah idealnya dilakukan 6 bulan sebelum melaksanakan pernikahan sebab rentang waktu 6 bulan cukup untuk melakukan pengobatan dan persiapan terhadap teknis pernikahan, namun pemeriksaan kesehatan pranikah dapat dilakukan kapan saja 
selama pernikahan belum berlangsung. Pada umumnya pemeriksaan kesehatan terbagi menjadi tiga bagian, yaitu :

1. Penyakit Menular Seksual (PMS)

Pemeriksaan kesehatan pranikah bisa menghindari adanya penularan penyakit yang ditularkan lewat hubungan seksual, seperti sifilis, gonorrhea, HIV dan hepatitis. Apabila penyakit menular ini ditemukan pada salah satu atau kedua pasangan, sebaiknya berobat terlebih dahulu sampai sembuh total sebelum melaksanakan pernikahan, sehingga resiko penyakit akan menular ke pasangan akan berkurang. Jika keduanya tetap ingin menikah dianjurkan berkonsultasi dengan dokter terkait untuk mencari solusi terbaik;

2. Penyakit Keturunan

Bagi pasangan yang memiliki riwayat penyakit keturunan seperti diabetes, asma dan penyakit-penyakit kelainan darah maka lebih berhati-hati dan menjaga diri dari faktor pencetus penyakit supaya tidak menurunkan penyakit yang dibawanya pada anaknya kelak. Dengan melakukan pemeriksaan kesehatan sebelum menikah, kemungkinan-kemungkinan penyakit yang akan terjadi setelah pernikahan bisa terdeteksi sejak dini. Ketika dari pemeriksaan tersebut ditemukan adanya penyakit seperti gangguan darah, thalasemia, leukimia, diabetes, kanker ataupun HIV/AIDS maka kesepakata untuk melanjutkan ke jenjang pernikahan adalah mutlak keputusan kedua calon mempelai. Dokter akan memberikan gambaran resiko yang akan dihadapi pasangan dan keturunannya; 
3. Ketidakcocokan Rhasus Darah

Premarital check up juga dapat mengungkapkan apakah ada ketidakcocokan rhesus darah yang dapat mempengaruhi kualitas keturunan. Adanya perbedaan golongan darah tertentu dapat membahayakan janin. Misalnya jika ibu memiliki golongan darah $\mathrm{O}$, sementara janinnya memiliki golongan darah A atau B maka keguguran dapat terjadi. Hal itu dapat disebabkan adanya penolakan dari antibodi ibu terhadap antigen yang terdapat pada darah janin tersebut. ${ }^{9}$

Pemeriksaan kesehatan sebelum menikah lebih lengkap diuraikan dalam buku yang berjudul Meraih Berkah Dengan Menikah, sebagai berikut :

1. Biasanya pemeriksaan pranikah meliputi pemeriksaan hematologi rutin dan analisa hemoglobin untuk mengetahui adanya kelainan atau penyakit darah;

2. Gambaran darah tepi, untuk mengetahui kelainan penyakit darah, seperti thalasemia ${ }^{10}$;

3. Laju endap darah (LED), untuk mengetahui proses inflamasi (Peradangan);

4. Golongan darah dan rhesus faktor, untuk mengetahui kemungkinan golongan darah calon bayi;

5. Pemeriksaan urin lengkap, untuk memantau fungsi ginjal dan penyebab lain yang berhubungan dengan ginjal atau saluran 201-203.

${ }^{9}$ Ajen Dianawati, From Single to Couple (Jakarta : Gagas Media, 2010), h.

10 Thalasemia adalah kelainan darah yang diturunkan dari orang tua, kelainan ini membuat penderitanya mengalami kurang darah atau anemia. 
kemih, pemeriksaan golongan darah dann rhesus yang akan berguna bagi calon janin;

6. Pemeriksaan gula darah untuk memantau kemungkinan diabetes mellitus ${ }^{11}$;

7. Pemeriksaan HbsAG untuk mengetahui kemungkinan peradangan hati (Hepatitis $B)^{12}$;

8. Pemeriksaan VDLR/RPR untuk mengetahui adanya kemungkinan penyakit sifilis ${ }^{13}$;

9. Pemeriksaan TORCH ${ }^{14}$ untuk mendeteksi infeksi yang disebabkan parasit toksoplasma, virus rubella, virus cytomegalo (CMV) dan virus Herves yang bila menyerang pada perempuan di masa kehamilan akan mengakibatkan komplikasi pada janin. ${ }^{15}$

Selain itu juga dilakukan pemeriksaan penunjang melalui laboratorium yang diperlukan oleh calon pengantin, antara lain : (1) Pemeriksaan darah, meliputi: Hb, golongan darah, dan rhesus. (2) Dalam kondisi tertentu/ atas saran dokter dapat dilakukan pemeriksaan laboratorium sebagai berikut; gula darah, HIV, IMS

11 Diabetes adalah penyakit yang berlangsung lama atau kronis serta ditandai dengan kadar gula (glukosa) darah yang tinggi atau di atas nilai normal.

12 Hepatitis B adalah peradangan organ hati yang disebabkan oleh virus Hepatitis B. Virus ini dapat menular melalu hubungan seksual atau berbagi jarum suntik.

13 Sifilis atau Raja Singa adalah penyakit menular seksual yang disebabkan oleh bakteri. Gejala sifilis dimulai dengan munculnya luka yang tidak terasa sakit di area kelamin ataupun dubur.

14 TORCH merupakan singkatan dari toksoplasmosis, other infection (infeksi lain), rubella, cytomegalovirus dan herves simplex virus.

15 M. Thobroni Dan Aliyah Munir, Meraih Berkah dengan Menikah (Yogyakarta: Pustaka Marwa, 2010), 91-92. 
(sifilis), hepatitis, TORCH, malaria, thalassemia, dan pemeriksaan lain sesuai indikasi.

\section{ANALISIS PREMARITAL CHECK UP DALAM PERSPEKTIF MAQASHID AL-SYARI'AH}

Tes Kesehatan Praknikah (Premarital Check Up) dalam Perspektif maqashid al-syari'ah yaitu dalam proses pemilihan pasangan untuk seumur hidup maka telah diatur dalam Islam yaitu berdasarkan Hadis yang artinya sebagai berikut; Dari abu Hurairah, dari Rasulullah, beliau bersabda : "perempuan itu dinikahi karena emapt hal, yaitu : harta, keturunan, kecantikan, dan agamanya. Maka nikahilah wanita yang taat beragama, niscaya engkau akan bahagia."Hadis Muttafaq Alaihi dan riwayat imam Lima. ${ }^{16}$

Dari Hadis tersebut dapat dipahami bahwa pemilihan pasangan yang terpenting adalah faktor agama yaitu haruslah benar-benar seakidah, selain faktor agama (hifzh din), ada beberapa faktor yang telah disebutkan dalam hadis tersebut yaitu mempertimbangkan hartad, keturunan dan kecantikan. Dalam tes kesehatan pra nikah secara subtansial juga telah mendukung hadis tersebut yaitu dengan tujuan untuk menjaga keturunan (hifzh nasl).

Selain hadis tersebut Nabi saw. memberi nasihat kepada Mughirah agar ia melihat perempuan yang hendak ia khitbah. Karena dengan melihat dapat tercipta kebaikan hubungan antara

16 Ibnu Hajar al-Asqalani, Bulughul Maram min Adilatil Ahkam, Terj. Harun Zen Dan Zenal Mutaqin (Bandung : Penerbit Jabal, 2013), 245. 
suami dan isteri serta dapat mewujudkan kasih sayang di antara keduanya. ${ }^{17}$

Tes kesehatan pranikah berdasarkan kuliyatul khamsa atau lima tujuan pokok hukum Islam yaitu menjaga agama, menjaga jiwa, menjaga keturunan, menjaga akal dan menjaga harta, maka tes kesehatan pranikah akan sesuai dengan lima tujuan pokok hukum Islam yaitu menjaga jiwa (hifz nafs), akal (hifz 'aql), keturunan (hifz nasl), dan harta (hifz mâl), hanya saja dalam hal ini lebih ditekankan masuk pada kategori menjaga jiwa (hifzh nafs) dan menjaga keturunan (hifzh nasl).

Jika dilihat dari sisi hifz nafs atau menjaga jiwa maka tes kesehatan pranikah merupakan suatu proses yang harus dilakukan karena dengan melakukannya maka itu adalah salah satu upaya untuk melindungi diri dari serangan penyakit yang akan menyebabkan jiwa terancam, hal ini karena tes kesehatan pranikah merupakan aplikasi dari konsep saad az-dzarî’ah atau pencegahan dari penularan penyakit dan pendeteksian penyakit lebih dini. Dalam kategori menjaga jiwa maka proses tes kesehatan pranikah masuk dalam kategori Maqâshid Hajiyyât yang merupakan kebutuhan sekunder dari manusia dan bukan merupakan kebutuhan primer bagi manusia. Apabila tidak melakukan tes kesehatan pranikah maka tidak akan mengancam keselamatan jiwa, namun nantinya hanya akan menyulitkan saja

17 Wahbah az-Zuhaili, Fiqih Islam Wa Adilatuhu, Terj. Abdul Hayyie AlKattani dkk (Depok: Gema Insani, 2016), 34. 
bila terjadi suatu penyakit yang menular akibat dari hubungan suami isteri yang tidak terdeteksi terlebih dahulu penyakitnya.

Ada beberapa penyakit menular seksual (PMS) yang dapat menular melalui hubungan seksual, sebagai berikut :

1. Gonore

Gonore adalah penyakit yang gejalanya tidak disadari oleh pengidapnya atau bahkan tidak disertai gejala. Akan tetapi, ketika gejalanya sudah mulai muncul, pengidapnya akan mengalami rasa gatal, rasa terbakar saat buang air kecil hingga mengalami keputihan. Gonore merupakan salah satu penyakit menular melalui hubungan seksual, infeksi bakteri merupakan faktor utama dari penyakit gonore. Penyebarannya dapat melalui penis, vagina, anus dan mulut seseorang yang telah terinfeksi.

2. Hepatitis

Hepatitis A,B, C merupakan virus yang menyerang hati, virus. Virus ini dapat ditularkan melalui cairan tubuh ketika berhubungan seksual. Heptitis bisa menyebabkan komplikasi berupa sirosis, kanker hati dan gagal hati.

3. Sipilis

Penyakit sipilis gejala awalnya bisa berupa banyak luka kecil dan melepuh, luka ini akan muncul di sekitar kuman sipilis masuk ke dalam tubuh. Penyakit ini dapat menyebar melalui penis, vagina, oral, anal maupun kontak kulit.

4. Herpes genital

Herpes genital dapat ditularkan melalui hubungan intim yang disebabkan oleh virus yang beranama herpes simpleks. 
5. Kutil Kelamin

Penyakit kutil kelamin merupakan penyakit akibat dari infeksi virus yang bernama Human Papillomavirus (HPV). Kutil kelamin bisa muncul setelah beberapa bulan atau tahun seseorang telah terinfeksi HPV. Kutil kelamin merupakan kutil yang muncul di sekitar alat kelamin atau di dubur. ${ }^{18}$

Maka dalam ini tes kesehatan pranikah akan sesuai dengan tujuan hukum Islam yaitu menjaga jiwa. Dalam Al-Qur'an disebutkan bahwa Qishash merupakan jaminan kehidupan bagi manusia, karena qishash merupakan upaya agar manusia tidak saling membunuh supaya tetap hidup dan dapat lebih bertakwa, dalam surat al-Baqarah (2) : 179 yang artinya sebagai berikut;"Dan dalam qishash itu ada (jaminan) kehidupan bagimu, wahai orang-orang yang berakal, agar kamu bertakwa."

Ayat tersebut adalah salah satu bukti bahwa tujuan hukum Islam adalah untuk melindungi jiwa. Jika di qiyaskan dengan tujuan dari tes kesehatan pranikah maka hal ini memiliki korelasi yang sama, yaitu sama-sama menjaga jiwa dari ancaman yang datang. Jika qishash dilaksanakan untuk mencegah dari terjadinya penghilangan nyawa (jiwa), maka tes kesehatan juga sama yaitu mencegah dari terjadinya penularan penyakit yang dapat mengancam keselamatan nyawa (jiwa) seseorang, namun perbedaannya adalah jika qishash masuk kategori ad-dharuriyyat maka tes kesehatan pranikah masuk kategori hajiyat.

18 Redaksi Halodoc, "Penyakit Menular Seksual (PMS)", www.halodoc.com/5-penyakit-menular-lewat-hubungan-seksual , 2020. 
Dari sisi menjaga keturunan (hifz nasl) maka tes kesehatan pranikah masuk dalam kategori kebutuhan sekunder karena tes kesehatan pranikah sebagai upaya untuk melindungi anak-anak yang akan lahir dari berbagai penyakit turunan yang dimiliki oleh orang tua seperti diabetes. Gen orang tua sangat mempengaruhi untuk berkembangnya penyakit yang diturunkannya, karena memiliki darah yang sama. Jika seseorang tidak melakukan tes kesehatan pranikah maka tidak apa-apa dikarenakan ini bukanlah tindakan yang wajib baik itu dalam perintah syari'at maupun hukum nasional. Namun bila sudah ada indikasi gejala penyakit sebelum menikah maka lebih baik untuk meminta saran pada dokter, untuk mempertimbangkan bagaimana kondisi kesehatan sang anak pada saat nantinya sudah lahir, melihat rekam jejak orang taunya yang menderita suatu penyakit.

Menjaga keturunan juga merupakan bagian dari tujuan pokok hukum Islam sebagaimana dalam al-Qur'an Allah berfirman yang artinya sebagai berikut; "Dan janganlah kamu mendekati zina; Sesungguhnya zina itu adalah suatu perbuatan yang keji. dan suatu jalan yang buruk". Ayat tersebut memerintahkan untuk tidak mendekati zina ${ }^{19}$ karena zina merupakan salah satu dosa besar, seseorang yang melakukan dosa zina harusalah bertaubat dengan taubat yang sesungguhnya. Zina sangatlah dilarang oleh agama karena dapat merusak tatanan nasab manusia yang harusnya dinisbatkan ke seorang laki-laki (ayah), namun justru harus ke perempuan (ibu). Sedangkan tes kesehatan pranikah adalah upaya

19 Zina adalah memasukkan dzakar ke dalam khasafah yang bukan istrinya. 
yang dilakukan untuk memperoleh keturuanan yang sehat dan tidak memiliki kelainan, hal tersebut memiliki kesamaan dengan larangan mendekati zina yang sama-sama memiliki tujuan yaitu untuk menjaga keturunan. Perintah menjaga keturunan dengan cara menjauhi zina masuk dalam kategori dharuriyyat karena hal itu merupakan ancaman utama dalam menjaga keturunan. Sedangkan tes kesehatan pranikah masuk kategori hajiyat karena hal tersebut hanyalah opsi sekunder yang dilakukan agar keturunan memiliki tubuh yang sehat. "Dari Anas bin Malik, ia berkata : Rasulullah memerintahkan kami untuk berkeluarga dan sangat melarang kami melajang (tidak menikah). Rasulullah bersabda "Nikahilah perempuan yang subur dan penyayang, sebab dengan jumlah kalian yang banyak aku akan berbangga di hadapan para Nabi pada hari kiamat kelak". Diriwayatkan oleh Ahmad dan dinyatakan sahih oleh Ibnu Hibban".20

Hadis tersebut merupakan perintah untuk menikah dan larangan agar tidak menikah, karena menikah mempunyai keutamaan di dalamnya. Selain perintah untuk menikah dan larangan tidak menikah, dalam hadis tersebut diperintahkan agar menikahi seorang yang memiliki kesuburan dalam reproduksinya. Untuk mengetahui bahwa seorang subur atau tidaknya sulit untuk di deteksi atau di obesrvasi tanpa menggunakan alat bantu dan ilmu yang ahli dalam bidangnya.

Kesuburan atau vertilitas dapat diketahui oleh calon pengantin dengan melakukan tes kesehatan di klinik ataupun 
rumah sakit, apabila salah satu calon pengantin diketahui memiliki tingkat kesuburan yang rendah maka dapat diobati terlebih dahulu sebelum melaksanakan pernikahan. Misalnya pada calon pengantin laki-laki ditemukan adanya invertilitas atau ketidaksuburan maka selain menjalani pengobatan, faktor-faktor yang menyebabkan invertilitas dapat dihindari terlebih dahulu seperti merokok. Jika pada calon pengantin perempuan terjadi obesitas maka akan mempunyai risiko invertilitas yang lebih tinggi, oleh sebab itu harus menurunkan berat badan menjadi lebih ideal untuk dapat mengurangi tingkat ketidaksuburannya.

Ditinjau dari segi menjaga akal (hifz 'aql) maka tes kesehatan pranikah suatu proses yang penting untuk dilakukan supaya dapat mencegah dari resiko penyakit yang dapat merusak akal pikiran baik pasangan maupun keturunan yang akan dilahirkan, terutama kepada anaknya. Dalam Islam ada beberapa pengharaman pernikahan antara laki-laki dengan perempuan sebab nasab maupun sebab persusuan, karena pernikahan tersebut akan membuat lemah keturunan dan timbulnya penyakit yang disebabkan oleh pernikahan antar kerabat. Berbeda dengan pernikahan yang dilakukan dengan orang yang memiliki hubungan yang jauh, yang dapat melahirkan keturunan yang kuat, sebagaimana yang telah dibuktikan secara medis dan syariat.

Dalam sebuah atsar yang artinya sebagai berikut: "Menjauhlah kalian agar lahir keturunan yang tidak lemah." 21 Maksudnya adalah diperintahkan untuk menikahi seorang yang jauh nasabnya agar tidak sampai lahir keturunan yang lemah, baik

21 Wahbah az-Zuhaili, Fiqih Islam wa Adilatuhu, 127. 
secara fisik, mental dan akal. Oleh sebab itu untuk menjaga akal adalah bagian dari bentuk rasa syukur atas nikmat yang Allah swt. berikan kepada manusia. Menjaga akal adalah perintah agama yang harus dilaksanakan, karena dengan akal pikiran manusia berbeda dengan hewan.

Tes kesehatan pranikah ( premarital check up ) dilihat dari menjaga harta (hifz mâl) merupakan tindakan pencegahan agar tidak terjadinya pengeluaran harta yang lebih banyak lagi untuk melakukan pengobatan di rumah sakit akibat dampak dari penularan penyakit yang di derita oleh salah satu pasangan pengantin ataupun sebagai tindakan preventif dari semakin parahnya penyakit yang di deritanya. Dalam proses pemeriksaan kesehatan juga dibutuhkan dana yang tidak sedikit, yaitu tergantung jenin pemeriksaan yang diinginkan oleh pasien yang akan melakukan tes kesehatan pranikah, semakin lengkap check up yang dijalani maka akan semakin mahal biaya yang dikeluarkannya. Apabila seseorang melakukan pemeriksaan kesehatan sebelum menikah, maka itu lebih baik daripada melakukan pengobatan pasca menikah yang diakibatkan oleh semakin parahnya penyakit yang di derita ataupun penularan penyakit dari pasangannya. Dalam kategori ini maka tes kesehatan pranikah masuk dalam kategori kebutuhan sekunder atau maqâshid hajiyât yaitu tujuan agar tidak mengeluarkan harta yang lebih banyak lagi, jika tidak melakukannya maka tidak akan mengancam keutuhan harta yang dimilik oleh orang tersebut. 


\section{KESIMPULAN}

Melakukan tes kesehatan pra nikah maka dapat diketahui lebih awal berbagai kemungkinan penyakit yang di derita sehingga dapat diambil tindakan lebih dini untuk mencegah berbagai kesulitan yang akan datang, hal ini sesuai dengan teori saad addzarî’ah atau pengambilan langkah preventif terhadap segala sesuatu yang dapat mengancam. Dalam analisa maqasid syariah yaitu menjaga agama (hifzh dîn), menjaga jiwa (hifzh nafs), menjaga keturunan (hifzh nasl), menjaga akal (hizfh 'aql) dan menjaga harta (hizfh mâl), tes kesehatan pranikah dalam hal ini lebih ditekankan sesuai dengan menjaga jiwa (hifzh nafs) dan menjaga keturunan (hifzh nasl). Tes kesehatan pra nikah dalam pandangan Maqâshid Al-Syarî̀ah dianjurkan karena melihat banyaknya manfaat di dalam pemeriksaan tersebut.

\section{DAFTAR PUSTAKA}

Al-Asqalani, Ibnu Hajar. Bulûghul Maram Min Adilatil Ahkam, Terj. Harun Zen dan Zenal Mutaqin. Bandung : Penerbit Jabal, 2013.

Al-Fanjari, Ahmad Syauqi. Nilai Kesehatan dalam Syariat Islam, Jakarta : Bumi Aksara.

Al-Mahalli, Al-Imam Jalaluddin Muhammad bin Ahmad bin Muhammad dan Al-Imam Jalaludiin Abdirrahman bin Abu Bakar As-Suyuthi. Tafsir Jalalain Jilid 1, Terj. Najib Junaidi. JATIM: IKAPI, 2015.

Al-Qardhawi, Yusuf. Fiqih Praktis Bagi Kehidupan Modern. Kairo : Maktabah Wabah, 1999.

Az-Zuhaili, Wahbah. Fiqih Islam wa Adilatuhu, Penerjemah Abdul Hayyie Al-Kattani dkk. Depok: Gema Insani, 2016.

Dianawati, Ajen. From Single to Couple. Jakarta : Gagas Media, 2010.

Djazuli, A. Fiqh Siyasah. Bandung: Prenada Media, 2003. 
Redaksi Halodoc. "Penyakit Menular Seksual (PMS)", www.halodoc.com/5-penyakit-menular-lewat-hubunganseksual , 2020.

Shihab, M. Quraish. Wawasan Al-Qur'an. Bandung : Mizan, 1998.

Susilo, Edi. "Penentuan Jenis Kelamin Khuntha Dengan Pendekatan Medis Dan Maqasid Shari'ah". Disertasi, UIN Sunan Apel Surabaya, 2017.

Thobroni, M. dan Aliyah Munir. Meraih Berkah dengan Menikah. Yogyakarta: Pustaka Marwa, 2010. 